\title{
Pestisida Efek Toksik dan Nasibnya di Lingkungan
}

\section{Oleh : Achmad Mursyidi}

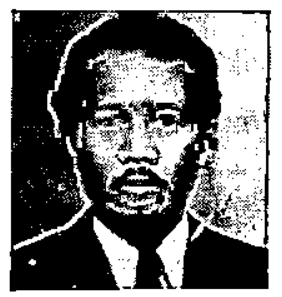

Dr. Achmad Mursyid, M.Sc, Apt., lahir di Boyolali, 8 Agustus 1944. Sarjana Farmasi 1972 (UGM) Apoteker, 1973 (UGM), Graduate Diploma Food \& Drug Analysis, 1978 (UNSW-Sydney); M.Sc, 1979 (UNSW-Sydney); Ph.D, 1987 (UNSW-Sydney). Guru SMA Muh. I (19671973), dosen Fak. Farmasi UGM (1973 - sampai sekarang).

Publikasi (5 tahun terakhir) Photochemical Reaction of Thisamides. (J.Photochem. Photobial, 1990); Oxidation of Thioureas with Photochemically, generated singlet Oxygen (J. Photocehm and photobial., 1992); Fotooksidasi Terpacu DDT (Majalah Farmasi Indonesia, 1992); Photochemistry of some Organosulphur Pesticides (J. Photochem Photobiol., 1992); Fotodegradasi Senyawa Organoklorin dengan Katalis Titandioksida (Majalah Farmasi Indonesia., 1994).

\section{Pendahuluan}

Penggunaan pestisida untuk pertanian, utamanya insektisida, fungsisida, dan herbisida, cenderung selalu meningkat. Langkah itu memang manpu meningkatkan produksi pangan, namun dalam jangka panjang terbukti telah menimbulkan dampak lingkungan yang cukup meresahkan.

Beberapa pestisida, utamanya insektisida organoklorin yang dikenal sangatstabil di lingkungan, dilaporkan telah mengkontaminasi bahan pangan di beberapa daerah (Noegrohati, dkk, 1984). Akibat stabilitasnya yang sangat tinggi; insektisida organoklorindapat tersebarluas, mencapai organisme non-target jauh dari tempat aplikasinya (Peakal. 1970).
Dilaporkan bahwa burung Pinguin dari KutubSelatan mengidap DDT cukup tinggi.

Satu hal yang patut dicatat ialah bahwa keberadaan pestisida di lingkungan merupakan hasil kegiatan manusia secara sengaja dan berkesinambungan. Oleh karena itu nasib pestisida di lingkungan : penyebaran, peruraian, interaksinya dengan faktor lingkungan, dan sebagainya, perlu diketahui sebagai landasan upaya' pelestarian lingkungan yang lebih baik.

Pestisida dapat didefinisikan sebagai bahan kimia yang digunakan untuk membasmi organisme yang tidak dikehendaki.

Berdasarkan jenis organisme target, pestisida dibedakan sebagai insektisida, fungsida, herbisida, nematosida, 
rodentisida, molusida dan virusida.

Secara kimiawi pestisida dibedakan atas pestisida anorganik dan organik. Pestisida anorganik banyak digunakan dimasa lampau; antara lain Na-arsenat, tembaga arsenat basa, dan timbal arsenat (insektisida); sulfur, bubur Bordeaux, tembaga klorida, tembaga-seng-kromat, timerosal dan senyawa $\mathrm{Hg}$-organik (fungisida); ferisulfat, amonium sulfamat, boraks, K-sianat (herbisida).

Kebanyakan pestisida yang digunakan saat ini adalah senyawa organik, utamanya senyawa sintetik. Beberapa pestisida organik alamiah (diperoleh dari tanaman) dapat disebutkan misalnya piretrin, rotenon, nor-nikotin, anabasin dan rianodin (Buchel, 1983).

Pestisida organik sintetik biasanya dibedakan atas 4 golongan yaitu organoklorin, organofosfat, karbamat dan golongan lain.

Pestisida organoklorin umumnya merupakan senyawa poliklor, bersifat non polar, sangat stabil dan larut dalam lemak. Pestisida ini meliputi jenis senyawa sangat luas (alifatik, aromatik, heterosiklik, alisiklik), demikian pula penggunaannya (insektisida, fungisida, herbisida). Oleh sifatnya yang sangat stabil, pestisida golongan ini banyak menimbulkan problema lingkungan, utamanya DDT, aldrin, lindan dan analognya.

Pestisida organofosfat yang mulamula dikembangkan oleh Gerhard Scrader mempunyai struktur umum.

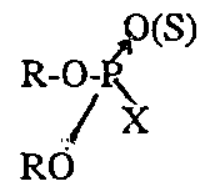

$\mathrm{X}$ dapat berupa gugus alifatik, aromatik, maupun heterosiklik.

Sifat kimia dan fisika pestisida organofosfat sangat bervariasi, bergantung pada variabilitas $X$.

Berdasarkan sifat ini insektisida organofosfat dapat digunakan sebagai insektisida kontak (mevinphos, tetraetilfosfat), insektisida sistemik (dimetoat, formation), dan fumigan (diklorofos, sulfotep).

Sementara itu pestisida $\cdot$ karbamat mempunyai rumus umum.

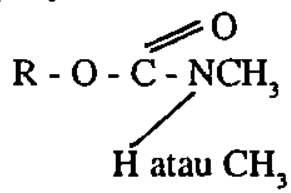

Kalau atom $O$ pada gugus karbonil digảnti dengan atom $S$, senyawa analog ini dikenal sebagai tiokarbamat yang turunannya banyak digunakan sebagai fungisida.

Pestisida ini dikembangkan berdasarkan senyawa alamiah fisostigmin yang terdapat dalam tanaman Physostigmus $\mathrm{sp}$.

Kebanyakan turunan karbamat digunakan sebagai insektisida, molusida, dan nematosida, sedangkan turunan tiokarbamat (sulfur-analogkarbamat) digunakan sebagai fungisida.

Seperti halnya organofosfat, variabilitas aktivitas pestisida karbamat bergantung pada variasi gugus $R$. Dilaporkan bahwa ribuan turunan karbamat telahdisintesis dan diuji aktivitasnya, tetapi hanya beberapa yang dapat dikembangkan secara komersial.

Selain ketiga golongan diatas masih ada pestisida turunan urea (linuron, monuran dan diuron), turunan anilin (trifluralin), turunan benzimidazol 
(tiabendazol), dan insektisida piretroid (analog piretrin).

\section{Pembahasan}

\section{Toksikologi Pestisida}

Diantara pestisida yang paling banyak mendapatkan perhatian para ahli toksikologị lingkungan adalah insektisida organoklorin. Sebagai agen neurotoksik, sebenarnya insektisida ini tidak terlalu toksik dibanding insektisida lain (LD-50 relatif besar). Namun demikian, oleh sifatnya yang sangat stabil dan kelarutannya yang besar dalam lemak, insektisida organoklorin, utamanya DDT, dapat mengalami biokonsentrasi berantai dan tersebar ke seluruh permukaan bumi. Oleh proses ini, kandungan DDT dalam jaringan lemak burung dapat mencapai $10 \mathrm{ppm}$ (Peakal, 1970) dan dapat mencapai burung pinguin di Kutub Selatan.
DDT diketahui menghambät enzim karbonik anhidrase, menyebabkan gangguan metabolisme unsur Ca sehingga telor yang dihasilkan sangat rapuh. Kenyataan ini mènyebabkan pecahnya telur sebelum saatnya menetas dan diduga sebagai penyebab menurunnya populasi burung Pelikan di P. Bermuda.

Pada hewan mamalia, dan diduga berlaku pula pada manusia, DDT menginduksi ' enzim lever yang mengakibatkan menurunnya kadarhormon estrogen. Selain itu DDT dan organoklorin menghambat ATP-ase sehingga terjadi gangguan metabolisme glukose. Sementara itu dilaporkan oleh National Cancer Institute bahwa DDT mempercepat kanker lever, paru dan limfa (Peakal; 1970).

Proses biokonsentrasi berantai DDT dapat dilukiskan dengan skema sebagaiberikut (Edwards, 1973).

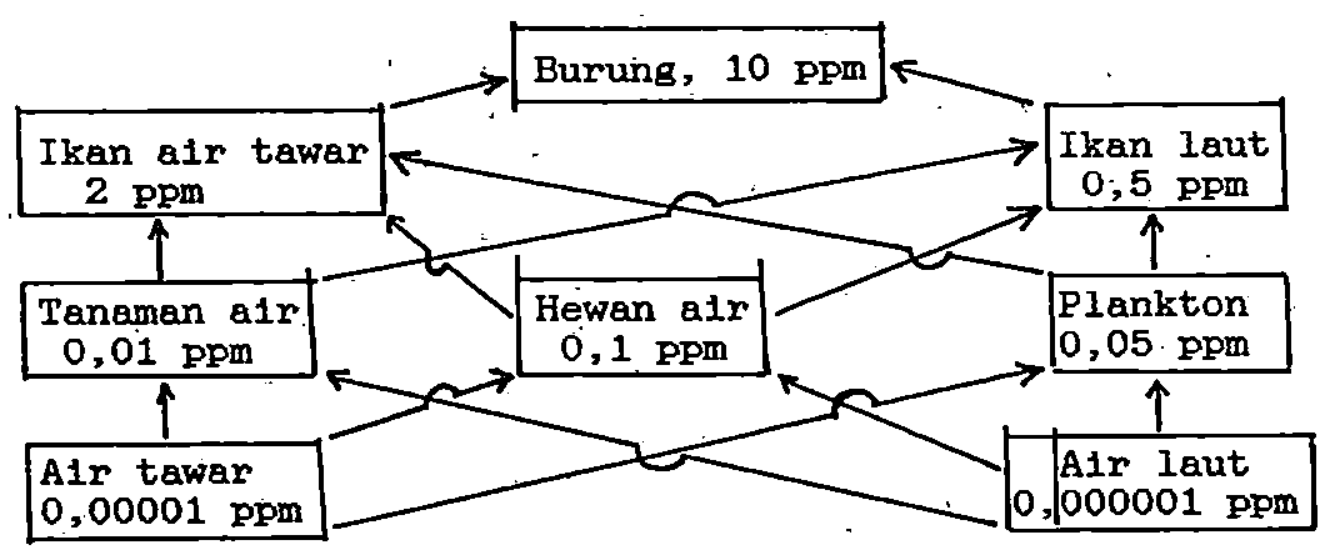


Berbeda dengañ DDT, senyawa poliklor yang digunakan sebagai herbisida (MCPA, 2-4, D) relatif lebih mudah mengalami degradasi di lingkungan. Namun demikian, beberapa herbisida golongan ini dikawatirkan bersifat teratogenik. (Khera and Mc. Kinley, 1972).

Kalau organoklorin bekerja sebagai neurotoksik, organofosfat dikenal sebagai inhibitor enzim kholin esterase. Insektisida ini lebih toksik dibanding organoklorin, tetapi lebih kecil dampak negatifnya dilingkungan karena insektisida organofosfat lebih cepat mengalami degradasi. Waktu paro insektisida organofosfat hanya beberapa jam sampai beberapa hari (Buchel, 1983), sedangkan waktu paro organoklorin dapat mencapai beberapa tahun.

Selain itu toksisitas organofosfat terhadapmanusia (mamalia) biasanya lebih rendah dibanding terhadapseranggakarena jarak antara gugus anionik dan esterik yang menupakan bagian aktif pada enzim kholin esterase pada serangga $\left(5,0-5,5 \mathrm{~A}^{\circ}\right)$ lebih besar dibanding pada manusia $(4,3-4,7$ $A^{\circ}$ ). Sedangkan jarak gugus anionik dan esterik pada insektisida organofosfat mirip dengan yang ada pada serangga, sehingga interaksinya lebih kuat.

Seperti halnya insektisida organofosfat, insektisida karbamat juga berfungsi scbagai inhibitor enzim kholin esterase. Perlu dicatat toksisitas insektisida ini relatif tinggi (aldicarb : LD-50:1 $\mathrm{mg}$ / $\mathrm{kg}$ ), namun masih dianggap lebih aman dibanding organofosfat. Hal ini dikarenakan kompleks antara karbamat dengan enzim kholin esterase lebih cepat terhidrolisis (beberapa menit) dibanding kompleks organofosfat-enzim (beberapa jam-hari). Ini berarti bahwa sifat toksik insektisida karbamat tidak bersifat kumulatif (Buchel, 1983) -

Daftar LD-50 (mg/kg tikus)

\begin{tabular}{llllll}
\hline Organoklorin & LD-50 & Organosfat & LD-50 & Karbamat & LD-50 \\
\hline DDT & $250-500$ & Etion & 96 & Dimetilen & 54 \\
Lindan & $76-250$ & Timet & 2 & Primikarb & 147 \\
Klordan & $283-590$ & Paration & 6,4 & Karbaril & 850 \\
Heptaklor & $90-135$ & Diazinon & 108 & Aminokarb & $30-50$ \\
Endosilfan & 100 & Fenamifos & $15-20$ & Propoksur & $90-128$ \\
Aldrin & 67 & Difonat & $8-17$ & Promekarb & $74-90$ \\
Dieldrin & $40-87$ & Mevinfos & 3,7 & Karbofuran & $8-14$ \\
Endrin & $7,5-17,5$ & Fosfamidon & 10 & Aldikarb & 0,93 \\
\hline
\end{tabular}




\section{Nasib Pestisida di Lingkungan}

Pada umumnya pestisida akan mengalami degradasi (peruraian) di lingkungan. Kecepatan degradasi tersebut sangat bergantung pada faktor inheren (kelarutan, polaritas, struktur dan ukuran molekul dsb) dan faktor lingkungan (cuaca, suhu, cahaya, air, mikroba dan sebagainya). Hasil degradasi pestisida biasanya kurang toksik, tetapi beberapa produk degradasi terbukti lebih toksik dibanding pestisida asli.

Pada dasamya degradasi pestisida di lingkungan dapat berlangsung lewat tiga cara yaitu :

a. Degradasi kimiawi yang dipengaruhi oleh adanya senyawa kimia tertentu di lingkungan.

b. Degradasi mikrobial yang dipengaruhi oleh mikroorganisme.

c. Degradasi fotokimia yang dipengaruhi oleh cahaya

a. Degradasi kimiawi

Kecepatan degradasi pestisida sangat dipengaruhi oleh senyawa organik maupun anorganik yang ada di dalam tanah. Reaksi yang mungkin berlangsung dapat berupa hidrolisis, oksidasi, reduksi dan isomerisasi.

Herbisida klor-triazin misalnya diketahui mengalami hidrolisis lebih cepat dalam tanah dari pada dalam airtanpa tanah. Lebih lanjut diketahui bahwa hidrolisis ini dikatalisis oleh proses sorpsi pada bahan organik tanah (Russel et al : 1968)

Reaksi hidrolisis juga lazim dialami oleh insektisida organofosfat. Kecepatan hidrolisis ini sangat dipengaruhi oleh $\mathrm{pH}$. Selain itu juga dipengaruhi oleh sorpsi, suhu dan kekuatan ion. Sementara itu hidrolisis malation, berlangsung dalam suasana basa sedangkan hidrolisis diazinon sangat dipengaruhi oleh sorpsi dan dipercepat oleh kenaikkan suhu. Selain itu reaksi oksidasi dialami oleh aldrin menghasilkan dieldrin (Decker and Biggar, 1965)dan parationmenghasilkan paraokson yang lebih toksik (Guesi and Beard, 1967). Terbentuknya paraokson dilaporkan sebagai penyebab terjadinya kerancunan pada para petani yang menggunakan paration sebagai pembasmi hama. Reaksi reduksi terjadi padadegradasi DDT menjadi DDE, yang lebih lanjut diketahui bahwa reaksi reduksi tersebut dikatalisis oleh ion besi (II) (Glass, 1972).

\section{b. Degradasi}

mikrobial

\section{(biodegradasi)}

Degradasi tipe ini sangat penting dalam proses lenyapnya pestisida di lingkungan. Degradasi mikrobial memungkinkan sempurnanya degradasi pestisida menghasilkan produk nontoksik karena berbagai jenis mikrooganisme dapat saling bekerja sama. Bahkan ada yang mampu memanfaatkan pestisida sebagai sumber energi (co-metabolisme). Mikroorganisme yang banyak terlibat pada proses degradasi mikrobial antara lain : Arthrobacter, Aspergillus, Corynebacterium, Flavobacterium, Fusarium, Nocardia, Penicillium, Pseudomonas, dan Trichoderma (Goring et al. 1975)

Beberapa tipe reaksi degradasi mikrobial a.l. dehalogenasi, hidrolisis, oksidasi, dan reduksi.

Dehalogenasi merupakan proses biodegradasi yang lazim dialami oleh pestisida organoklorin. DDT mengalami deklorinasi menghasilkan DDE, sedangkan BHC oleh bakteria diuraikan menghasilkan benzen. Reaksi deklorinasi juga terjadi pada 
metoksiklor dan lindan.

Seperti halnya degradasi kimiawi, proses hidrolisis juga merupakan degradasi mikrobial insektisida organofosfat. Malation misalnya dihidrolisis oleh Psedomonas dan Trichoderma. Sementara itu hidrolisis herbisida urea dipengaruhi oleh berbagai bakteri (Psedomonas, Xanthomonas, Bacillus) dan fungi (Penicillium dan Aspergillus), sedangkan hidrolisis herbisida karbamat dipengaruhi oleh Arthrobacter dan Achromobacter.

Oksidasi mikrobial banyak dialami oleh pestisida organoklorin menghasilkan senyawa hidroksi yang lebih mudah larut yangmemungkinkan proses degradasi lebih lanjut. Mikroorganisme yang banyak terlibat dalam degradasi ini adalah Nocardia yang mampu mensintesis enzim oksigenase.

Reduksi mikrobial banyak dijumpai pada pestisida dengan gugus nitro, misalnya paration, fenition, trifuralin, dan PCBN. Pada proses ini gugus nitro direduksi menghasilkan gugus amina.

\section{c. Degradasi} (fotodegradasi)

fotokimiawi

Fotodegradasi berawal dari absorpsi cahaya (matahari) oleh suatu molekul, menghasilkan molekul tereksitasi dengan energi tinggi. Molekul ini tidak stabil dan cenderung kembali ke keadaan dasar via reaksi fotokimia. Tipe reaksi kimia yang terjadi bergantung pada struktur molekul dan lingkungan.

Pada penggunaannya, pestisida dilingkungan akan terekspose cahaya matahari. Oleh karena itu fotodegradasi merupakan proses yang sangat mungkin terjadi pada pestisida. Kemungkinan itu lebih besar di daerah tropik yang memiliki intensitas cahaya matahari cukup tinggi.

Pestisida + hu ---> Pestisida* ---> fotodegradasi

Kenyataan juga menunjukkan bahwa pestisida yang mengabsorpsi cahaya di daerah uv (dieldrin $215 \mathrm{~nm}$ dan 2-4, D 230 $\mathrm{nm}$ ) mengalami fotodegradasi di lingkungan. Padahal radiasi cahaya matahari yang mencapai permukaan bumi lebih besar $290 \mathrm{~nm}$. Ini berarti bahwa telah terjadi transfer energi oleh agen pemeka cahaya (sensitizing agent) terhadapmolekul pestisida. Reaksi sensitisasasi ini dapat dilukiskan :

Pc+hu $\quad .->\quad$ Pc*+Pestisida $\quad . .->$ Pc+Pestisida* ${ }^{*--}>$ fotodegradási

Dengan prinsip seperti itu berbagai tipe reaksi fotodegradasi dialami oleh pestisida, a.l. : dehalogenasi, hidrolisis, oksidasi, substitusi, dealkilasi, kondensasi.

- Dehalogenasi (deklorinasi)

merupakan reaksi fotodegradasi kebanyakan pestisida organoklorin. Oleh pengaruh cahaya, DDT akan diuraikan secara lambat menghasilkan DDE yang kurang toksik. Oleh adanya oksigen dan pemeka cahaya, DDT terdegradasi menghasilkan DDD, DDE dan DDCO. Reaksi semacam itu dikenal sebagai fotooksidasi terpacu dan berlangsung relatif cepat. (Mursyidi, 1992)

Dalam larutan, dieldrin mengalami deklorinasi membentuk pentaklorodieldrin, sedangkan dalam keadaan padat akan menghasilkan foto dieldrin.

Beberapa jenis herbisida 
organoklorin mengalami deklorinasi dan diikuti subsitusi hidroksilasi menghasilkan polifenol yang lebih lanjut berkondensasi membentuk asam humat (humic acid). Proses ini memungkinkan herbisida organoklorin lebih cepat lenyap di lingkungan dibanding golongan DDT.

- Reaksi foto-hidrolisis merupakan proses degradasi yang dominan pada insektisida organofosfat. Selain itu, oleh pengaruh cahaya matahari, debu paration mengalami fotooksidasi menghasilkan para okson yang lebih toksik.

Seperti halnya organofosfat, fotodegradasi yang dominan pada insektisida karbamat adalah hidrolisis. Metil-2-benzimidazol karbamat misalnya, akan terhidrolisis menghasilkan karbometoksi guanidin, karbometoksi guanin, dan guanidin. Selain hidrolisis, fungisida tiokarbamat dan juga fungisida lain yang mengandung unsur belerang (folpet, kaptan, dan kaptafol) mengalami fotooksidasi menghasilkan belerang dioksid. Reaksi fotoksidasi semacam ini ,jugadialamiberbagaisenyawa organosulfur dan akan dipercepat oleh adanya agen pemeka cahaya (Mursyidi, 1992).

Oleh karena di lingkungan banyak terdapat agen pemeka cahaya (misalnya klorofil), maka fotooksidasi terpacu merupakan proses fotodegradasi yang paling mungkin dialami oleh pestisida. Proses ini dapat menyerang segala macam jenis pestisida, karena oksigen singlet yang dihasilkan pada peristiwa transfer energi sistem ini sangat reaktif. Oleh sebab itu dapat dipahami kalau proses degradasi di daerahtropik berjalan lebihcepat dibanding daerah beriklim sedang. Dalam kaitan ini dilaporkan bahwa DDT di daerah tropik dapat lenyap hanya dalam beberapa bulan (Mustofa, et al., 1989).

Satu tipe fotodegradasi lain yang dialami pestisida adalah dealkilasi. Reaksi ini banyak dijumpai pada pestisida turunan anilin yang mengandung gugus alkil pada atom $\mathrm{N}$, misalnya monuron dan linuron.

Kesimpulan

Di lingkungan, secara alamiah pestisida akan mengalami degradași. Sekalipun begitu, karena percepatan penambahannya melebihi kemampuan lingkungan melakukan degradasi, efek toksik sulit dihindarkan.

Efek toksik pestisida di lingkungan sangat ditèntukan oleh stabilitas kimianya. Insektisida organoklorin sangat stabil sehingga efek toksik dapat tersebar jauh dari tempat aplikasinya.

Degradasi pestisida di lingkungan, baik degradasi kimiawi, mikrobial maupun fotokimiawi menghasilkan senyawa yang memiliki struktur molekul yang berbeda dari senyawa aslinya. Oleh karena toksisitas (juga aktivitas) suatu senyawa berkaitan erat dengan struktur molekulnya, maka perubahan tersebut memungkinkan perubahan toksisitasnya.

Produk degradasi pada umumnya kurang toksik dibanding senyawa aslinya. Namun demikian tidak tertutup kemungkinan terbentuknya senyawa lebih toksik (misalnya paraokson).

Untuk memperkecil dan memperpendek dampak negatif, penggunaan dan pengembangan pestisida organosulfur merupakan altematif yang cukup menjanjikan, karena senyawa ini sangatpeka terhadap fotooksidasi sehingga memungkinkan lenyapnya pestisida di lingkungan. 


\section{Daftar Pustaka}

Buchel, K.H; (Ed), 1983, Chemistry of Pesticids, John Wiley dan \& Co, New York, 92, 154.

Decker, G.C., and Bigger, J.H., 1965; Accumulation or dissipation of Residues Resulting from the use of aldrin in soil, J. Econ and Entamol., 58,266.

Edwards, C.A; 1973, Persistent Pesticids in the Environment Second Edition, CRC Press. Inc. San Francisco.

Glass, B;I; 1972; Relation between the degradion of $D D T$ and the iron redox system in soil; J.Agr.Food Chem, $20,324$.

Goring, C.A. '1972; Laskwoki,D.A.; Hamaker, J.W.; and Meikle, R.W; 1975; dalam "Enviromental Dinamics of Pesticides.; Haque. $\mathrm{R}$ andFreed,H.V.(Eds); Plenum Press, New York, 135.

Guenzi W.D. and Beard, W.E.; 1967; Volatilation of lindone and DDTfrom soil, Science, 156, 1116.

Khera, K.S. and Mc. Kinley, W.P; 1972 Pre-and postnatal Studies on 2,4,5- trichlorophenoxyacetic acid, 2,4dichlorophenoxy acetic acid, and theirderivatves in Rats; Toxicol and Appl, Pharm; 22,14.

Mursyidi, A; 1992; Fotooksidasi Terpacu $D D T$, Majalah Farmasi Indonesia, Vol. 3 No. 1,17.

Mursyidi, A; 1992; Photochemistry of some Organosulphur Pesticides, J. Photochem, Photobial., A.Chem. ; 289 - 297.

Mustofa, I,Y, Zayed, S.M; and El-Arab, A.E. 1989, Studies on Disspation and Degradation of DDT in Egyption soil under Field Contitions.

Noegrohati S; Priatmoko, dan Haryono; 1984, Analisis Residu DDT dalam tanah di daerah Sleman, Kulon Progo, Bantul dan Gunung Kidul, simposium HKI, Yogyakarta.

Peakal, D. 1967; Pesticides and Reproduction of Bird; Scientific american; July, 1967, 13-17.

Russel, J.D; Cruz.M and White. J.L; 1968, Made of Chemical degradation of Striazin by montmorilomite; Science, $160,1340$. 